\title{
EFFECT OF HYDROGEL AND \\ ANTITRANSPIRANTS TREATMENTS ON THE PRODUCTIVITY OF SWEET BASIL (OCIMUM BASILICUM L.) PLANT
}

\author{
Rania M. Khater \\ Department of Medicinal and Aromatic Plants, Desert Research \\ Center, El-Matareya, Cairo, Egypt \\ E-mail: dr.raniakhater@yahoo.com
}

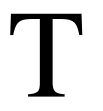

his investigation was conducted in El-Qantara Sharq Station, North Sinai, Desert Research Center, Egypt during the two successive seasons 2014 and 2015 to study the effect of applying certain antitranspirants (5\% kaolin and 6\% calcium carbonate), hydrogel levels $(0,1,2 \mathrm{~g} / \mathrm{plant})$ and the interaction between them on the vegetative growth parameters and essential oil production of the sweet basil (Ocimum basilicum L.). The results illustrate that the plant, which was sprayed with $5 \%$ kaolin produced the highest vegetative growth parameters, essential oil production measurement and chemical components. The different hydrogel levels significantly increased all growth characters. The highest values were produced from sweet basil plants with application with $2 \mathrm{~g}$ hydrogel /plant. Regarding the effect of the interaction between foliar application with antitranspirant and different hydrogel levels, the combined treatment of applying hydrogel level of $2 \mathrm{~g} / \mathrm{plant}$ with spraying the plants with $5 \%$ kaolin gave significant increase in all growth characters. The main components of essential oil were linalool, $\alpha$-terpineol and 1,8 cineol. The combined treatment of foliar kaolin application at 5\% level with hydrogel level of $2 \mathrm{~g} / \mathrm{plant}$ has given the highest content of linalool $(35.43 \%), \alpha$-terpineol $(27.80 \%)$ and 1,8 cineol (12.09\%), while decreased methyl chavicol (undesirable component) (0.75\%) compared with control plant and other treatments.

Keywords: sweet basil, Ocimum basilicum L., hydrogel, antitranspirants, kaolin, calcium carbonate

Basil or sweet basil (Ocimum basilicum L.) is an annual plant belongs to family Lamiaceae. Economically sweet basil is used in different fields; such as cookery, pharmaceutical and cosmetic productions (Marotti et al., 1996). In folk medicine, basil is well known to be used as carminative, galactogogue, stomachic and antispasmodic tonic, vermifuge, for treating 
nausea, flatulence and dysentery (Ozcan and Chalchat, 2002 and Sajjadi, 2006).

Much attention has been given to maintain favorable internal water balance in plants by suppression of water loss with film-type antitranspirants. Antitranspirants may be defined as a reflective material that decreases the heat load on leaf film forming materials that hinder the scope of water vapor form the leaf or stomata closing materials (metabolic) that increase stomatal resistance film (Prakash and Ramachandran, 2000). Antitranspirants also include the maintenance of more favorable water potential in essential for desirable growth (Gewefiel et al., 2009).

Some studies on spraying $6 \% \mathrm{CaCO}_{3}$, which is a film forming antitranspirant on plants like roselle, Nicotiana glauca, Mentha arvensis and potato showed increasing plant height, number of branches per plant and NPK contents (Mahfouz, 1997; Saudan et. al., 1999; El-Ghamriny et al., 2005 and Khater, 2010).

Kaolin is considered as a reflective antitranspirant that has the ability to decrease leaf temperature and reduce transpiration rate as a non-abrasive, non-toxic (aluminum silicate; $\mathrm{Al}_{4} \mathrm{Si}_{4} \mathrm{O}_{10}(\mathrm{OH})_{8}$ ) (Cantore et al., 2009). Spraying of the reflective antitranspirant kaolin on tomato led to stomata conductance decreasing by $53 \%$, hence increase in mean fruit weight and increased lycopene fruit content (Moftah and Al-Humaid, 2005). Applying kaolin product on apple improved yield, fruit size and color (Glenn et al., 2001).

Hydrogel is an absorbent polymer, which has the form of crystals working by absorbing water to make it available to plants over a period of time. Emesih et al. (1999) and Taylor and Halfacre (1986) mentioned that application of hydrogel improved the properties of porous soils for water storage and led to increase of water holding capacity and significantly reduce irrigation water requirements of many plants. Some studies on using hydrogel in soil planted with Trifolium sp., lettuce and ryegrass reported improvement of germination and biomass production (Ahmad and Verplancke, 1994).

The main objectives of the investigation were; (i) assessment the optimum hydrogel level applied to Ocimum basilicum plants to reduce irrigation water requirement, (ii) investigate the effect of spraying plants with different antitranspirants for reducing transpiration and (iii) determination the interaction between both investigated factors on vegetative growth, production of essential oil and chemical constituents of sweet basil plants.

\section{MATERIALS AND METHODS}

This experiment was taken place in El-Qantara Sharq Station, North Sinai, Desert Research Center, Egypt, through the two successive summer 
seasons of 2014 and 2015, to study the effect of hydrogel levels (control, 1 and $2 \mathrm{~g} /$ plant) and antitranspirants treatments (control, 5\% kaolin and 6\% $\mathrm{CaCO}_{3}$ ) as well as their interactions on the vegetative growth, essential oil production, chemical composition of sweet basil plants. The seeds of sweet basil plant were obtained from the Medicinal and Aromatic Plants Research Department, Horticulture Institute, Agricultural Research Center, Dokki, and the hydrogel were obtained from the El-Shura Chemical Company.

The first step of the experiment was sowing seedbeds on $1^{\text {st }}$ of March in both seasons of 2014 and 2015. Seedlings were transplanted after 45 days to the prepared plots on $15^{\text {th }}$ of April for both seasons. The area of each plot for planting was $12 \mathrm{~m}^{2}(3 \times 4 \mathrm{~m})$ and the distance between rows was $60 \mathrm{~cm}$, while distance between plants was $40 \mathrm{~cm}$. The physical and chemical analyses of experimental farm soil in El-Qantara Sharq Station are shown in table (1). All experimental units received equal amounts of water during both seasons. All plants have received similar chemical fertilization at rate of $200 \mathrm{~kg} / \mathrm{fed}$ of calcium superphosphate and $20 \mathrm{~m}^{3} / \mathrm{fed}$ of compost during soil preparation and $400 \mathrm{~kg} / \mathrm{fed}$ of ammonium sulfate and $100 \mathrm{~kg} / \mathrm{fad}$ of potassium sulfate were added as two equal parts. The first addition was done after one month from transplanting and the second one was added after the first harvest (cut) by two weeks. Plants received normal agricultural practices whenever they needed.

Table (1). Physical and chemical properties of the used soil in El-Qantara Sharq Station Desert Research Center, North Sinai, Egypt

\begin{tabular}{|c|c|c|c|c|c|c|c|}
\hline \multirow[b]{2}{*}{$\begin{array}{l}\text { Mechanical } \\
\text { analysis }\end{array}$} & \multirow[b]{2}{*}{ Value } & \multicolumn{6}{|c|}{ Chemical analysis } \\
\hline & & $\begin{array}{c}\text { Soluble anions } \\
(\mathrm{meq} / \mathrm{l})\end{array}$ & Value & $\begin{array}{c}\text { Soluble cations } \\
(\mathrm{meq} / \mathrm{l})\end{array}$ & Value & $\begin{array}{c}\text { Available } \\
(\mathrm{mg} / \mathrm{l})\end{array}$ & Value \\
\hline Fine sand \% & 43.28 & $\mathrm{CO}_{3}^{-}$ & - & $\mathrm{Ca}^{++}$ & 8.92 & $\mathbf{N}$ & 0.16 \\
\hline Coarse sand \% & 42.26 & $\mathrm{Cl}^{-}$ & 9.00 & $\mathbf{M g}^{++}$ & 7.95 & $\mathbf{P}$ & 13.21 \\
\hline Silt \% & 13.28 & $\mathrm{SO}_{4}^{--}$ & 25.35 & $\mathbf{N a}^{+}$ & 20.42 & $\mathbf{K}$ & 69.67 \\
\hline Clay \% & 1.18 & pH & 8.29 & $\mathbf{K}^{+}$ & 1.21 & $\mathrm{CaCO}_{3}$ & 6.20 \\
\hline Soil texture & & Sandy & & E.C mmhos $/ \mathrm{cm}$ & & 3.85 & \\
\hline
\end{tabular}

The experiment consisted of 9 treatments including the combinations between antitranspirants treatments (control, 5\% kaolin and $6 \% \mathrm{CaCO}_{3}$ ) and hydrogel levels (control, 1 and $2 \mathrm{~g} /$ plant). These treatments were arranged in a split plot design with three replicates. Antitranspirants treatments were randomly applied on the main plots, while hydrogel level treatments were randomly applied on the sub plots. Applying of hydrogel levels was firstly during soil preparation. Plants were sprayed with antitranspirants kaolin and $\mathrm{CaCO}_{3}$ two times, the first time was 30 days after transplanting and the second time after 30 days from each cut by using hand pressure sprayer. Distilled water was used to dilute all antitranspirants. Plants were sprayed with a fine mist of antitranspirants till run off, taking into consideration 
covering all plant parts. Each plot received four liter of antitranspirant aqueous solution. Control plants were sprayed with distilled water.

\section{Recorded Data}

- Vegetative growth parameters; including plant height, number of branches per plant and fresh and dry weights of herb per plant and per plot.

- Essential oil parameters; including essential oil percentage of herb that was determined in two cuts according to British Pharmacopoeia (1936), essential oil yield ( $\mathrm{ml} / \mathrm{plot}$ ) (yield of oil produced per plant was calculated by multiplying the average dry weight of herb per plant by the average oil percentage), and essential oil composition (the essential oil obtained from the herb was analyzed by using GLC according to Bunzen et al. (1969) and Hoftman (1967) methods.

- Chemical constituents; total nitrogen, phosphorus and potassium percentages were estimated, where nitrogen percentage was determined using Nissler method according to the procedure described by Koch and McMeekin (1924), phosphorus percentage was determined according to the method of Troug and Mayer (1939) and potassium determination was done using photometrically flame photometer according to the method described by Brown and Lilleland (1946). The plants were harvested two times through the growing season. The first and second cuts took place on $15^{\text {th }}$ of June and $15^{\text {th }}$ of September in both seasons, respectively.

\section{Statistical Analysis}

The recorded data were statistically analyzed and treatments were compared using significant difference L.S.D. test at 5\% level according to Snedecor and Cochran (1980) by using software (STATISTIX 9.0) Analytical Software (1985).

\section{RESULTS AND DISCUSSION}

\section{Plant Growth Characters}

\subsection{Effect of hydrogel levels}

The results of vegetative growth characters; i.e. plant height, number of branches per plant and fresh and dry weights of herb per plant and per plot, using different hydrogel levels are shown in table (2). The results reflected a significant increase that vegetative growth characters were enhanced significantly by increasing hydrogel levels in both cuts and seasons. Moreover, increasing hydrogel levels increased vegetative growth characters. The highest vegetative growth parameters were recorded on using hydrogel level $(2 \mathrm{~g} / \mathrm{plant})$. The highest values of plant height [ 80.40 and $85.80 \mathrm{~cm})$ and $(97.28$ and $99.56 \mathrm{~cm})]$, number of branches [(7.82 and 7.98) and (7.88 and 9.66)], fresh weight of herb/plant [(284.24 and 304.24 g) and 


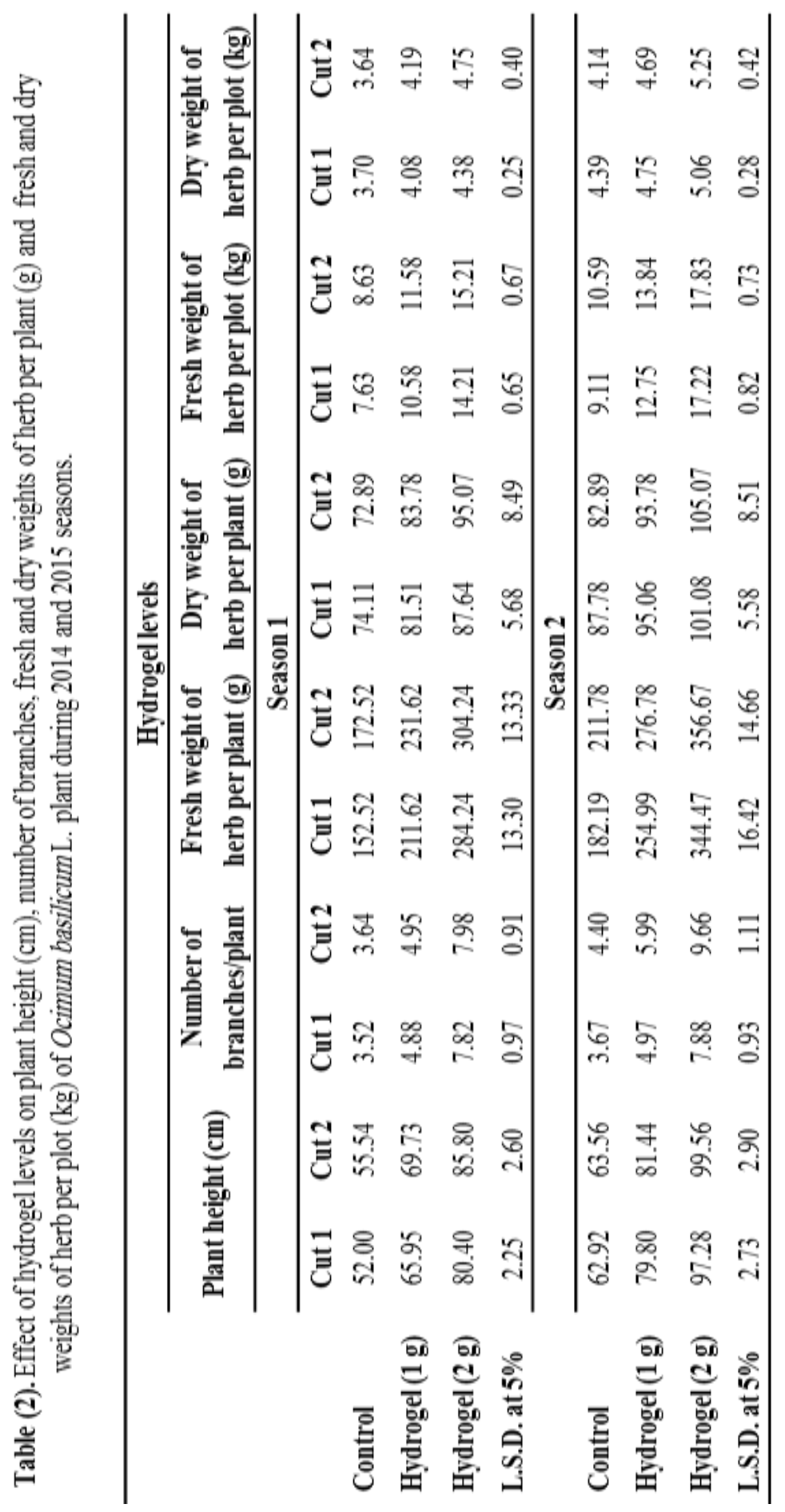

Egyptian J. Desert Res., 65, No. 2, 193-214 (2015) 
(344.47 and $356.67 \mathrm{~g})]$, dry weight of herb/plant [(87.64 and $95.07 \mathrm{~g})$ and $(101.08$ and $105.07 \mathrm{~g})$ ], fresh weight of herb/plot [(14.21 and $15.21 \mathrm{~kg})$ and $(17.22$ and $17.83 \mathrm{~kg})]$ and dry weight of herb/plot [(4.38 and $4.75 \mathrm{~kg})$ and $(5.06$ and $5.25 \mathrm{~kg})]$ were recorded when plants were treated with $2 \mathrm{~g}$ of hydrogel per plant in the first and second cuts in both seasons, respectively.

Increment of vegetative growth characters with increase of hydrogel levels due to increasing field capacity of soil will tend to an increase in keeping soil water and needed nutrients for growth around the roots, according to high level of hydrogel or as a result of water availability that increased cell enlargement and cell division also keep higher moisture content in the soil, and this might favor the plant metabolism that leads to the production of higher fresh and dry matter as mentioned by Abe and Nakai (1999).

The differences between the highest hydrogel level and the lowest one were significant in both seasons. The data in second season behave in the same manner as in first season. The decrease in hydrogel levels reduced soil moisture content and caused suffering of plants to get water requirements and these in turn might account much for depression in vegetative growth. The previous result is in harmony with those obtained by Akhter et al. (2004).

\subsection{Effect of antitranspirants}

The results of the main effect of antitranspirants in table (3) reflected that the treating of plants with antitranspirants resulted in significant increase in all vegetative growth parameters compared with untreated (control) plants. The treatment of 5\% kaolin gave superior values of these parameters. The highest values of plant height [(73.33 and $78.28 \mathrm{~cm})$ and $(88.73$ and 90.42 $\mathrm{cm})$ ], number of branches [(6.71 and 6.87) and (6.88 and 8.31)], fresh weight of herb/plant [(246.57 and 266.57 g) and (298.05 and 315.22 g)], dry weight of herb/plant [(103.41 and $108.89 \mathrm{~g})$ and $(116.57$ and $118.89 \mathrm{~g})]$, fresh weight of herb/plot [(12.33 and $13.33 \mathrm{~kg})$ and $(14.90$ and $15.76 \mathrm{~kg})]$ and dry weight of herb/plot [(5.17 and $5.45 \mathrm{~kg})$ and $(5.83$ and $5.95 \mathrm{~kg})]$ were recorded when plants were treated with foliar application of 5\% kaolin in the first and second cuts in both seasons, respectively. These results hold true during both seasons and two cuts.

The increments in plant growth parameters by using antitranspirant treatments may be attributed primarily to antitranspirant effect on increasing plant water potential at a time when the growth of that particular plant part was more dependent on water status than on photosynthesis (Boye, 1970). These results are in line with those reported by Jifon and Syvertsen (2003) and Liang et al. (2002). 


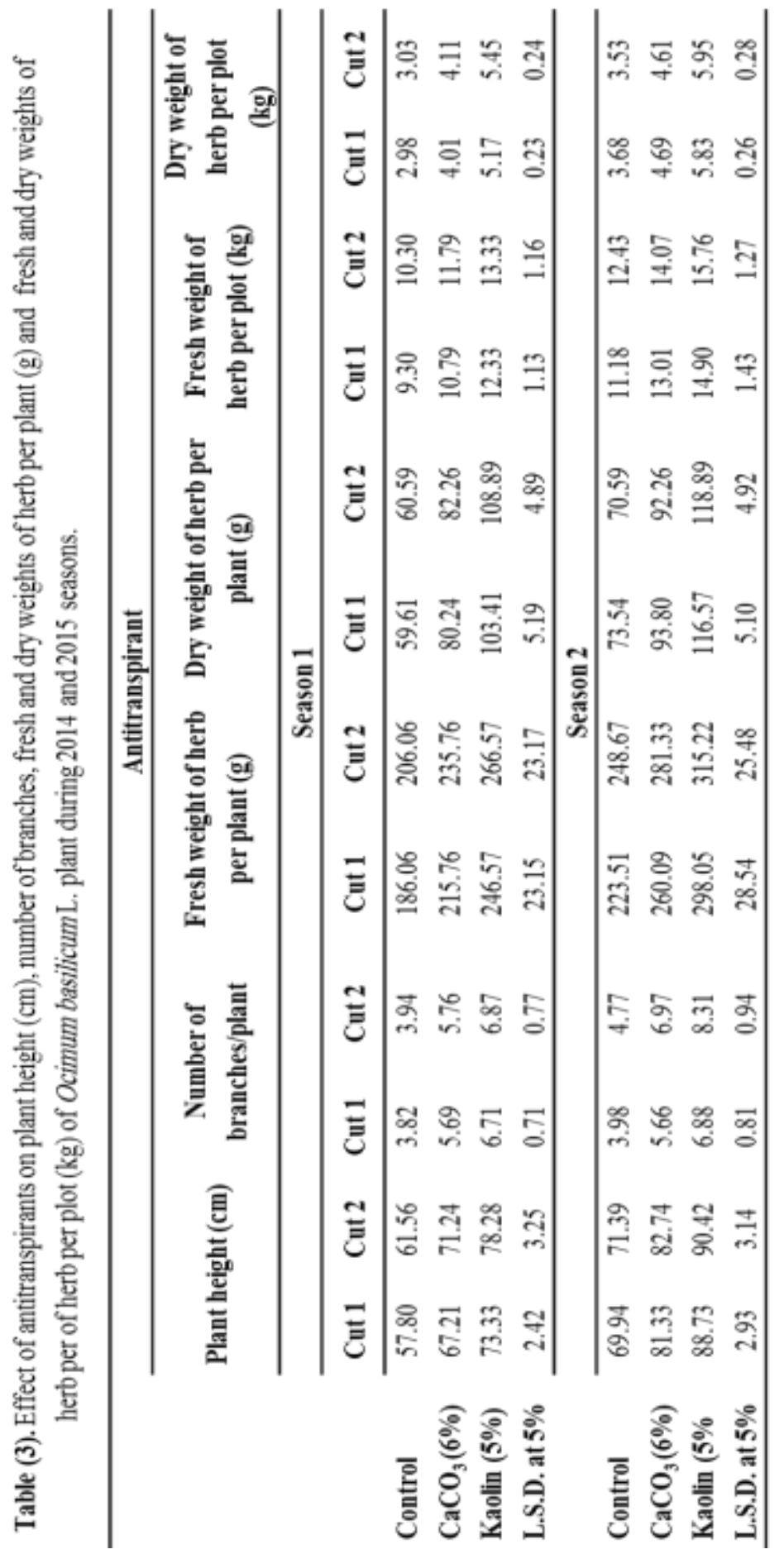

Egyptian J. Desert Res., 65, No. 2, 193-214 (2015) 


\subsection{Effect of the interaction}

Data in table (4) indicate that the interaction between different hydrogel levels and antitranspirants had a significant effect on the vegetative growth characters. The highest values of plant height $[(89.36$ and $96.93 \mathrm{~cm})$ and $(108.13$ and $111.00 \mathrm{~cm})]$, number of branches [(9.67 and 10.00) and (10.00 and 12.10)], fresh weight of herb/plant [(330.31 and 350.31 g) and (401.21 and $407.33 \mathrm{~g})$ ], dry weight of herb/plant [(115.17 and $125.78 \mathrm{~g})$ and $(128.12$ and $135.78 \mathrm{~g})]$, fresh weight of herb/plot [(16.52 and $17.52 \mathrm{~kg})$ and $(20.06$ and $20.37 \mathrm{~kg})]$ and dry weight of herb/plot [(5.76 and $6.29 \mathrm{~kg})$ and $(6.41$ and $6.79 \mathrm{~kg}$ )] were recorded when plants were treated with $2 \mathrm{~g}$ of hydrogel/plant and 5\% kaolin in the first and second cuts in both seasons, respectively. While spraying plants with $\mathrm{CaCO}_{3}$ and 1 or $2 \mathrm{~g}$ hydrogel gave increase of vegetative growth parameters, but did not reach to the level of significance. Similar results were recorded by Gewefiel et al. (2009) and Nakano and Uehara (1996).

\section{Essential Oil Production}

\subsection{Effect of hydrogel levels}

It is clear in table (5), that essential oil production parameters include essential oil percentage; essential oil yield per plant (ml) and essential oil yield (ml/plot) were gradually significantly increased with increasing hydrogel level. The highest values of these parameters were shown at the highest hydrogel level of $2 \mathrm{~g} / \mathrm{plant}$. The highest values of essential oil production parameters; essential oil percentage $[(0.308$ and $0.314 \%)$ and $(0.358$ and $0.327 \%)]$, essential oil yield per plant [(0.324 and $0.351 \mathrm{ml})$ and $(0.425$ and $0.398 \mathrm{ml})]$ and essential oil per plot [(16.218 and $17.572 \mathrm{ml})$ and (21.226 and $19.906 \mathrm{ml})]$ were recorded in the first and second cuts in both seasons, respectively. This result may be due to the fact that increasing hydrogel increases water holding capacity around the rhizosphere zone, that in turn increases minerals solubility in soil, photosynthesis, amino acids and oil productivity.

\subsection{Effect of antitranspirants}

The effects of antitranspirants treatments on essential oil percentage and essential oil yield (ml/plot) were reported in table (6). It was found that, treating plants with antitranspirants resulted in significant increase in essential oil parameters compared with untreated (control) plants. The highest values of essential oil percentage [ $(0.291$ and $0.303 \%)$ and $(0.343$ and $0.327 \%)]$, essential oil yield per plant $[(0.272$ and $0.306 \mathrm{ml})$ and $(0.366$ and $0.360 \mathrm{ml})$ ] and essential oil per plot [(13.582 and $15.313 \mathrm{ml})$ and $(18.016$ and $18.302 \mathrm{ml})]$ were recorded when plants were treated with foliar application of $5 \%$ kaolin in the first and second cuts in both seasons, respectively. This result may be due to that increment in antitranspirants increased the uptake of minerals from the soil by increasing the absorption processes, closure of the stomata and decreasing transpirations processes, 


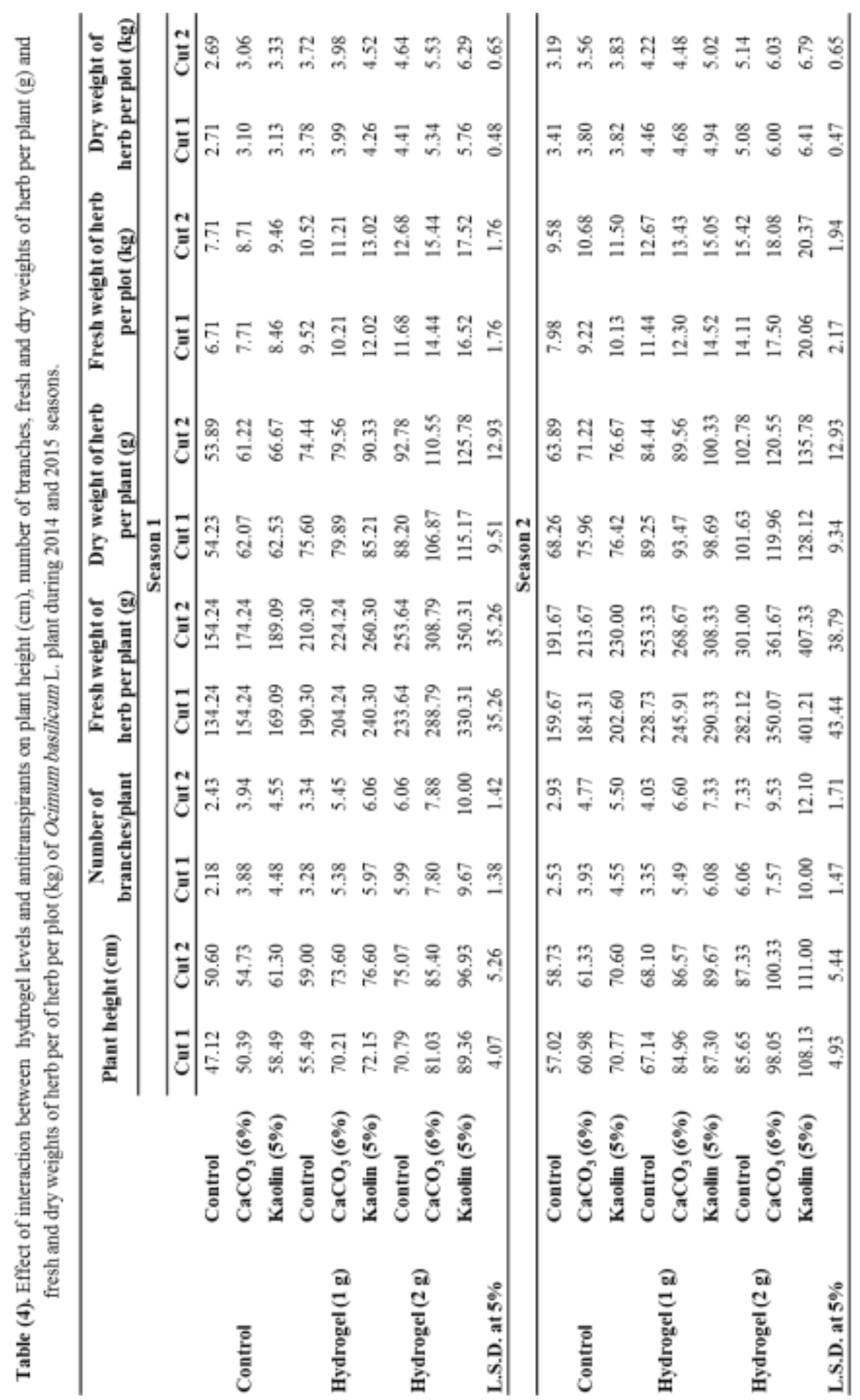

Egyptian J. Desert Res., 65, No. 2, 193-214 (2015) 
which reflecting increasing photosynthesis activity, amino acids and oil productivity.

\subsection{Effect of the interaction}

The best interaction treatment resulted in a significant effect on the highest essential oil parameters was by using hydrogel level of $2 \mathrm{~g} / \mathrm{plant}$ and antitranspirant kaolin at 5\%, during the first and second cuts in both seasons (table 7). The highest values of essential oil percentage [ $(0.383$ and $0.393 \%)$ and $(0.453$ and $0.413 \%)]$, essential oil yield per plant [ $(0.441$ and $0.495 \mathrm{ml})$ and $(0.581$ and $0.561 \mathrm{ml})]$ and essential oil per plot [(22.073 and $24.727 \mathrm{ml})$ and $(28.070$ and $29.040 \mathrm{ml})$ ] were recorded when plants were treated with 2 $\mathrm{g}$ of hydrogel/plant and 5\% kaolin in the first and second cuts in both seasons, respectively.

\section{Essential Oil Constituents}

The analysis of the most significant ingredients of the essential oils of basil plant in the second season, as well as the control treatment, is shown in table (8), to figure out the effect of hydrogel, antitranspirat and their interaction on the active ingredients of essential oils using GLC analysis. It was found that the increase in methyl chavecol compound percentage decreased the quality of essential oil. The best treatment that decreased the proportion of methyl chavecol in the essential oil was spraying plant with $5 \%$ kaolin and adding $2 \mathrm{~g} /$ plant hydrogel to the soil.

The percentage of the components was calculated and presented in table (8) and fig. (1, 2, 3, 4, 5, 6, 7, 8, 9). Data showed that Ocimum basilicum oil contents of $\alpha$ - pinene and $\beta$-pinene increased in all transactions compared to the control, but the treatment of calcium carbonate and $1 \mathrm{~g} / \mathrm{plant}$ hydrogel gave the highest percentage. The components of 1,8 cineol increased in all interactions compared to the control and its highest value was recorded when the plant was sprayed with kaolin and treated with 2 $\mathrm{g} / \mathrm{plant}$ hydrogel. The plants sprayed with kaolin and treated with $2 \mathrm{~g} / \mathrm{plant}$ hydrogel gave the highest value of linalool, while plant sprayed with calcium carbonate and $1 \mathrm{~g} / \mathrm{plant}$ hydrogel gave the lowest value of linalool compared to the other treatments. The components of $\alpha$-terpineol ratio decreased in both treatments of 1 and $2 \mathrm{~g}$ hydrogel /plant and spraying with calcium carbonate, while the proportion of $\alpha$-terpineol increased in all treatments. The highest value was recoded with the treatment of kaolin and $2 \mathrm{~g}$ hydrogel/plant. The components of geranial acetate ratio decreased in all treatments, while increased in the plants sprayed with kaolin only and plant sprayed with kaolin and $1 \mathrm{~g}$ hydrogel as compared to the control. The components of methyl chavicol ratio decreased in all treatments and gave less valuable with the treatment with kaolin and $2 \mathrm{~g}$ hydrogel /plant when compared with the other treatments. Increased $\beta$ - caryophyllene composite ratio was shown when the plant was sprayed with kaolin and $2 \mathrm{~g} /$ plant 
hydrogel, while spraying with kaolin only recorded the lowest percentage of this compound.

Table (5). Effect of hydrogel levels oil percentage, essential oil yield per plant (ml) and essential oil yield per plot (ml) of Ocimum

\begin{tabular}{lcccccc}
\hline & Oil percentage & $\begin{array}{c}\text { Essential oil yield } \\
\text { per plant (ml) }\end{array}$ & $\begin{array}{c}\text { Essential oil yield } \\
\text { per plot (ml) }\end{array}$ \\
\cline { 2 - 7 } & \multicolumn{5}{c}{ Season 1 } \\
& Cut 1 & Cut 2 & Cut 1 & Cut 2 & Cut 1 & Cut 2 \\
\hline Control & 0.159 & 0.167 & 0.096 & 0.103 & 4.774 & 5.133 \\
Hydrogel (1 g) & 0.246 & 0.254 & 0.198 & 0.211 & 9.886 & 10.557 \\
Hydrogel (2 g) & 0.308 & 0.314 & 0.324 & 0.351 & 16.218 & 17.572 \\
L.S.D. at 5\% & 0.021 & 0.028 & 0.042 & 0.022 & 0.541 & 1.090 \\
\cline { 2 - 7 } & \multicolumn{7}{c}{ Season 2 } \\
Control & 0.176 & 0.188 & 0.130 & 0.135 & 6.497 & 6.731 \\
Hydrogel (1 g) & 0.284 & 0.286 & 0.268 & 0.265 & 13.411 & 13.232 \\
Hydrogel (2 g) & 0.358 & 0.327 & 0.425 & 0.398 & 21.226 & 19.906 \\
L.S.D. at 5\% & 0.033 & 0.040 & 0.026 & 0.036 & 1.330 & 1.788 \\
\hline \multicolumn{7}{c}{ basilicum L. plant during 2014 and 2015 seasons. }
\end{tabular}

Table (6). Effect of antitranspirants on oil percentage, essential oil yield per plant (ml) and essential oil yield per plot (ml) of Ocimum basilicum L. plant during 2014 and 2015 seasons.

\begin{tabular}{lcccccc}
\hline & \multicolumn{7}{c}{ Oil percentage } & \multicolumn{2}{c}{$\begin{array}{c}\text { Essential oil yield } \\
\text { per plant (ml) }\end{array}$} & \multicolumn{2}{c}{$\begin{array}{c}\text { Essential oil yield } \\
\text { per plot (ml) }\end{array}$} \\
\cline { 2 - 7 } & \multicolumn{7}{c}{ Season 1 } \\
\cline { 2 - 7 } & Cut 1 & Cut 2 & Cut 1 & Cut 2 & Cut 1 & Cut 2 \\
\cline { 2 - 7 } Control & 0.184 & 0.191 & 0.143 & 0.146 & 7.144 & 7.281 \\
CaCO $_{3}(6 \%)$ & 0.237 & 0.241 & 0.203 & 0.213 & 10.151 & 10.668 \\
Kaolin (5\%) & 0.291 & 0.303 & 0.272 & 0.306 & 13.582 & 15.313 \\
L.S.D. at 5\% & 0.021 & 0.027 & 0.024 & 0.025 & 1.210 & 1.241 \\
\hline & 0.208 & 0.209 & 0.190 & 0.179 & 8.971 & 9.497 \\
\hline Control & 0.267 & 0.264 & 0.267 & 0.258 & 12.882 & 13.334 \\
CaCO (6\%) & 0.267 & \multicolumn{7}{c}{ Season 2 } \\
Kaolin (5\%) & 0.343 & 0.327 & 0.366 & 0.360 & 18.016 & 18.302 \\
L.S.D. at 5\% & 0.030 & 0.028 & 0.033 & 0.029 & 1.425 & 1.649 \\
\hline
\end{tabular}




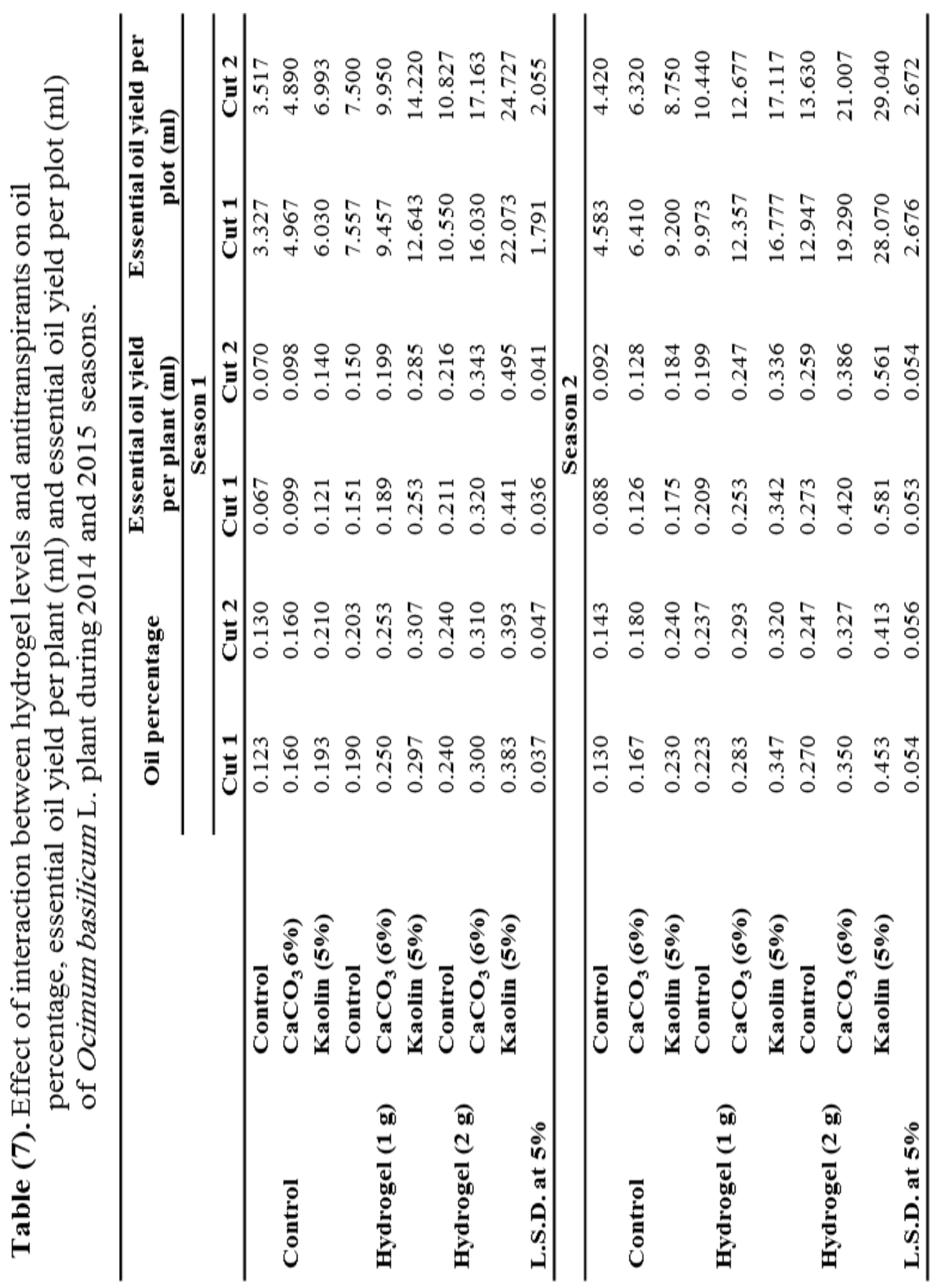

Egyptian J. Desert Res., 65, No. 2, 193-214 (2015) 


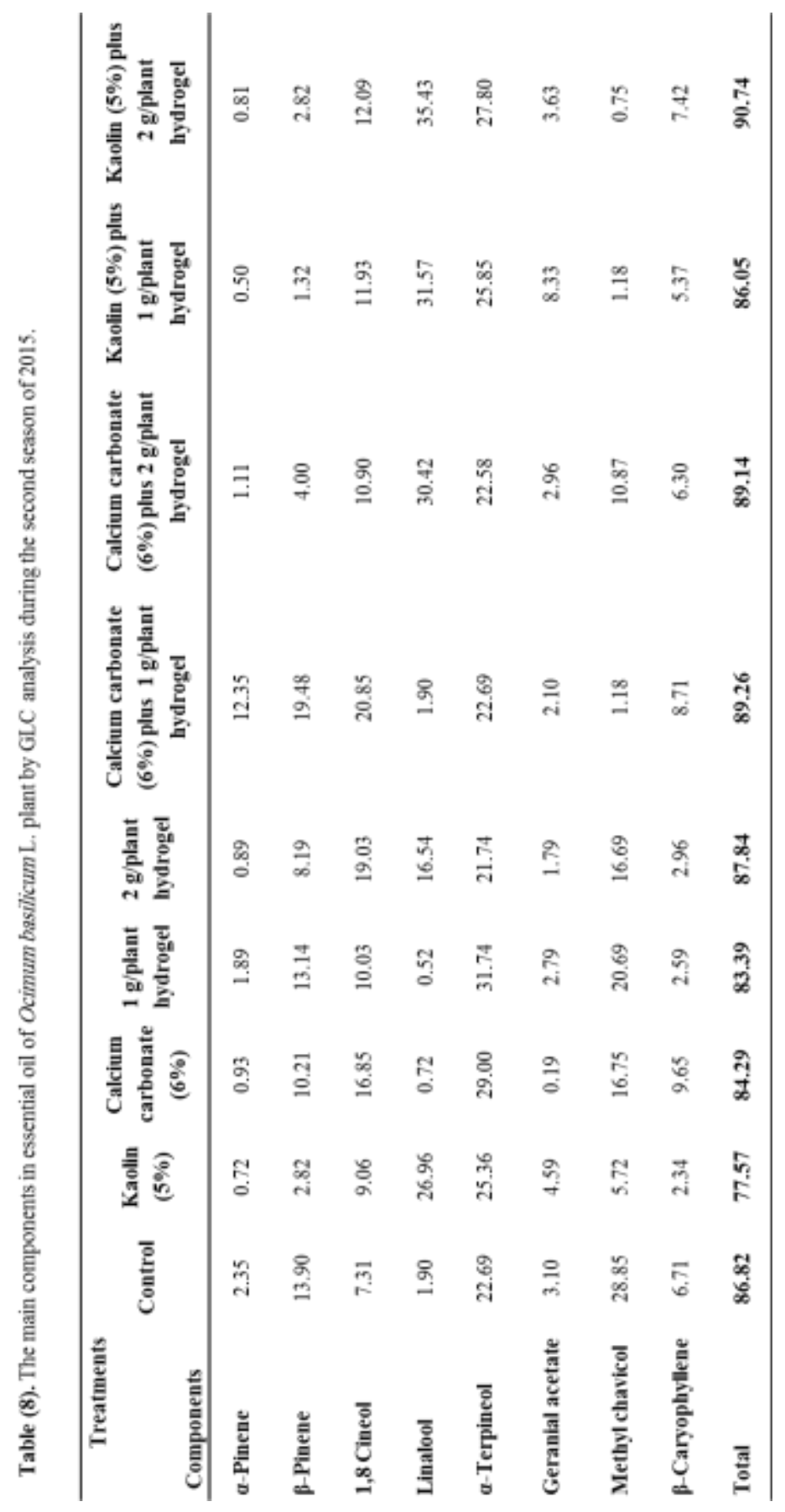

Egyptian J. Desert Res., 65, No. 2, 193-214 (2015) 


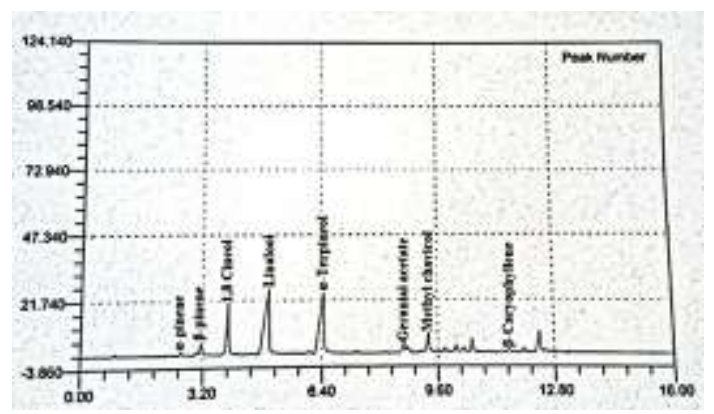

Fig. (1). Chromatogram of Ocimum basilicum L. oil extracted from plants treated with 5\% kaolin during the second cut in second season of 2015.

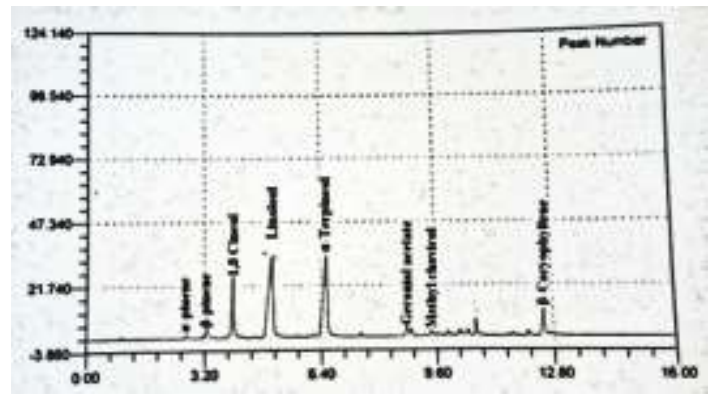

Fig. (2). Chromatogram of Ocimum basilicum L. oil extracted from plants treated with 5\% kaolin plus $1 \mathrm{~g}$ hydrogel /plant during the second cut in second season of 2015.

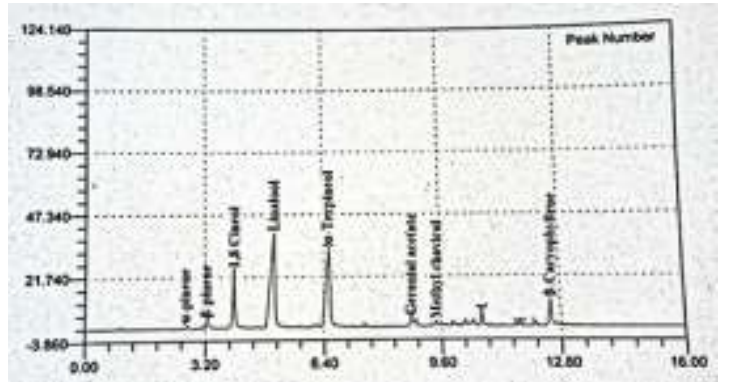

Fig. (3). Chromatogram of Ocimum basilicum L. oil extracted from plants treated with 5\% kaolin plus $2 \mathrm{~g}$ hydrogel /plant during the second cut in second season of 2015 .

Egyptian J. Desert Res., 65, No. 2, 193-214 (2015) 


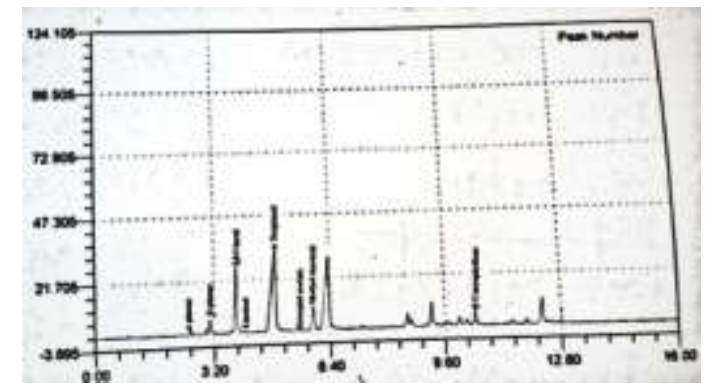

Fig. (4). Chromatogram of Ocimum basilicum L. oil extracted from plants treated with $6 \% \mathrm{CaCO}_{3}$ during the second cut in second season of 2015.

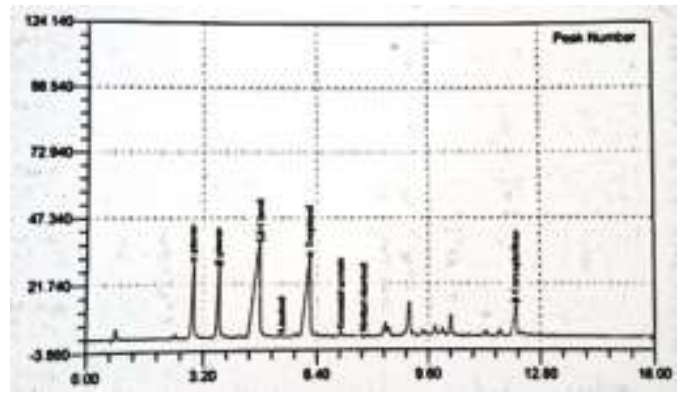

Fig. (5). Chromatogram of Ocimum basilicum L. oil extracted from plants treated with $6 \% \mathrm{CaCO}_{3}$ plus $1 \mathrm{~g}$ hydrogel /plant during the second cut in second season of 2015.

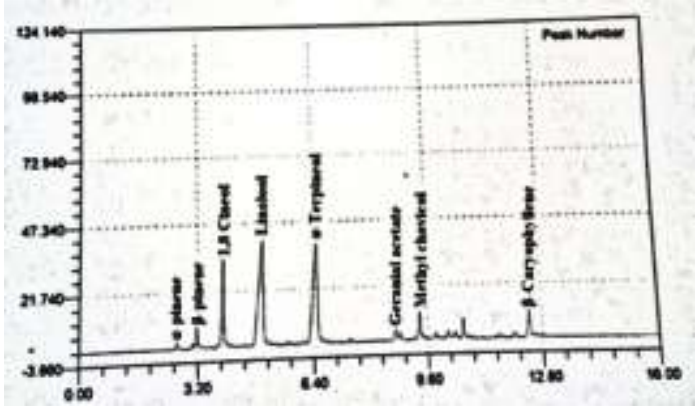

Fig. (6). Chromatogram of Ocimum basilicum L. oil extracted from plants treated with $6 \% \mathrm{CaCO}_{3}$ plus $2 \mathrm{~g}$ hydrogel /plant during the second cut in second season of 2015 .

Egyptian J. Desert Res., 65, No. 2, 193-214 (2015) 


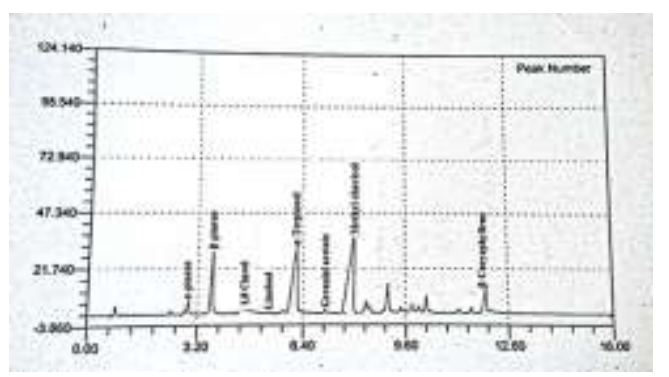

Fig. (7). Chromatogram of Ocimum basilicum L. oil extracted from control plants during the second cut in second season of 2015.

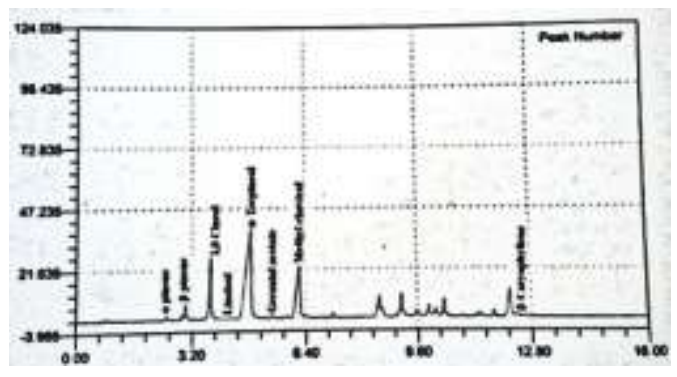

Fig. (8). Chromatogram of Ocimum basilicum L. oil extracted from plants treated with $1 \mathrm{~g}$ hydrogel /plant during the second cut in second season of 2015 .

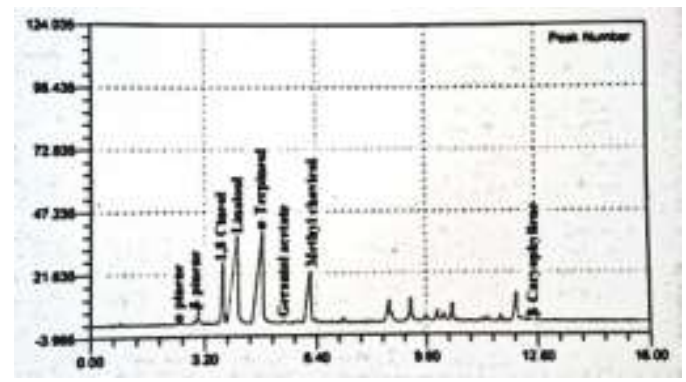

Fig. (9). Chromatogram of Ocimum basilicum L. oil extracted from plants treated with $2 \mathrm{~g}$ hydrogel /plant during the second cut in second season of 2015.

Egyptian J. Desert Res., 65, No. 2, 193-214 (2015) 


\section{Chemical Composition of the Plant \\ Nitrogen, phosphorus and potassium percentages \\ 4.1. Effect of hydrogel levels}

Data in table (9) show that nitrogen, phosphorus and potassium percentages were gradually significantly increased with increasing the hydrogel level up to $2 \mathrm{~g} / \mathrm{plant}$, which gave the highest values of these components. These results are in line with those recorded by Kosterna et al. (2012) and Nnadi and Brave (2011). The previous results may be due to the fact that increasing the hydrogel level led to increasing the water content in the soil within a reasonable range that made minerals more available to plant uptake and led to the enhancement of minerals accumulation in plant (Dufault and Hair, 1991).

\subsection{Effect of antitranspirants}

Results in table (10) declare that, the total nitrogen, phosphorus and potassium percentages were significantly increased when plants were treated with antitranspirant compared to untreated plants. The highest percentage of all these components have been obtained when plants were sprayed with kaolin at $5 \%$ in both seasons. The antitranspirations reduce water loss from the plant, thus increase the water into the cells and increase the absorption of water and mineral nutrients in the soil, as a result of the decreased transpiration and closure of the stomata. Similar results were reported by Martinez et al. (2001) and Moftah (1997).

\subsection{Effect of the interaction}

The combined effect between different hydrogel levels and antitranspirants recorded in table (11) show that the highest values of nitrogen, phosphorus and potassium percentages were obtained when plants were treated with hydrogel level of $2 \mathrm{~g} / \mathrm{plant}$ and sprayed with kaolin at $5 \%$ during both seasons, respectively. The interaction between antitranspirations and hydrogel levels may reduce water loss from the soil and thus increased the water around the roots to dissolve nutrients. As a result of increased water potential of the soil solution, this led to the transfer of water and nutrients to the plant, which increased its plant nutrients content.

The increasing of total carbohydrate percentages by using antitranspirants, hydrogel level and their interaction may be attributed to the increase in photosynthetic apparatus in large foliar area resulting in greatest efficiency in capturing of solar energy, in addition, the photosynthetic capacity of a cell is depending on the chlorophyll content. 
Table (9). Effect of hydrogel levels on nitrogen, phosphorus and potassium percentages of Ocimum basilicum L. plant during 2014 and 2015 seasons.

\begin{tabular}{ccccccc}
\hline & \multicolumn{2}{c}{ Nitrogen } & \multicolumn{2}{c}{ Phosphorus } & \multicolumn{2}{c}{ Potassium } \\
\cline { 2 - 7 } & Season 1 & Season 2 & Season 1 & Season 2 & Season 1 & Season 2 \\
\cline { 2 - 7 } Control & 1.57 & 1.63 & 1.69 & 1.80 & 0.259 & 0.268 \\
Hydrogel (1 g) & 2.31 & 2.36 & 2.07 & 2.20 & 0.360 & 0.372 \\
Hydrogel (2 g) & 2.58 & 2.65 & 2.77 & 2.87 & 0.431 & 0.451 \\
L.S.D. at 5\% & 0.24 & 0.23 & 0.19 & 0.19 & 0.049 & 0.045 \\
\hline
\end{tabular}

Table (10). Effect of antitranspirants on nitrogen, phosphorus and potassium percentages of Ocimum basilicum L. plant during 2014 and 2015 seasons.

\begin{tabular}{ccccccc}
\hline & \multicolumn{2}{c}{ Nitrogen } & \multicolumn{2}{c}{ Phosphorus } & \multicolumn{2}{c}{ Potassium } \\
\cline { 2 - 7 } & Season 1 & Season 2 & Season 1 & Season 2 & Season 1 & Season 2 \\
\cline { 2 - 7 } Control & 1.62 & 1.68 & 1.77 & 1.88 & 0.257 & 0.268 \\
CaCO $_{3}$ (6\%) & 2.19 & 2.25 & 2.25 & 2.38 & 0.367 & 0.376 \\
Kaolin (5\%) & 2.65 & 2.71 & 2.52 & 2.62 & 0.426 & 0.447 \\
L.S.D. at 5\% & 0.31 & 0.30 & 0.17 & 0.15 & 0.019 & 0.015 \\
\hline
\end{tabular}

Table (11). Effect of interaction between hydrogel levels and antitranspirants on nitrogen, phosphorus and potassium percentages of Ocimum basilicum L. plant, during 2014 and 2015 seasons.

\begin{tabular}{|c|c|c|c|c|c|c|c|}
\hline & & \multicolumn{2}{|c|}{ Nitrogen } & \multicolumn{2}{|c|}{ Phosphorus } & \multicolumn{2}{|c|}{ Potassium } \\
\hline & & Season 1 & Season 2 & Season 1 & Season 2 & Season 1 & Season 2 \\
\hline \multirow{3}{*}{ Control } & Control & 1.35 & 1.40 & 1.30 & 1.41 & 0.177 & 0.187 \\
\hline & $\mathrm{CaCO}_{3}(6 \%)$ & 1.55 & 1.60 & 1.82 & 1.94 & 0.277 & 0.287 \\
\hline & Kaolin $(5 \%)$ & 1.83 & 1.89 & 1.96 & 2.06 & 0.325 & 0.330 \\
\hline \multirow{3}{*}{ Hydrogel (1 g) } & Control & 1.73 & 1.79 & 1.90 & 1.97 & 0.288 & 0.294 \\
\hline & $\mathrm{CaCO}_{3}(6 \%)$ & 2.41 & 2.47 & 2.00 & 2.17 & 0.358 & 0.366 \\
\hline & Kaolin (5\%) & 2.78 & 2.82 & 2.31 & 2.47 & 0.433 & 0.456 \\
\hline \multirow{3}{*}{ Hydrogel (2 g) } & Control & 1.80 & 1.86 & 2.10 & 2.25 & 0.307 & 0.322 \\
\hline & $\mathrm{CaCO}_{3}(6 \%)$ & 2.60 & 2.68 & 2.93 & 3.02 & 0.466 & 0.476 \\
\hline & Kaolin (5\%) & 3.35 & 3.42 & 3.28 & 3.33 & 0.520 & 0.554 \\
\hline L.S.D. at $5 \%$ & & 0.50 & 0.48 & 0.31 & 0.28 & 0.056 & 0.050 \\
\hline
\end{tabular}




\section{REFERENCES}

Abe, I. and T. Nakai (1999). The effect of the water status within a tree on tracheid morphogenesis in Cryotomeria japonica. D. Den. trees. Structure and Function, 14 (3): 124-129.

Ahmad, M. and H. Verplancke (1994). Germination and biomass production as affected by salinity in hydrogel treated sandy soil. Pakistan J. Forest., 44: 53-61.

Akhter, J., K. Mahmood, K.A. Malik, A. Mardan, M. Ahmad and M.M. Iqbal (2004). Effects of hydrogel amendment on water storage of sandy loam and loam soils and seedling growth of barley, wheat and chickpea. Plant Soil Environ., 50: 463-469.

Analytical Software (1985). Data analysis software for researchers 1985.

Boye, J.S. (1970). Leaf enlargement and metabolic rate in corn, soybean and sunflower at various leaf water potential. Plant Physiol., 46: 233235.

British Pharmacopoeia (1936). In "Determination of Volatile Oil in Drugs". Published by the Pharmaceutical Press, London.

Brown, J.D. and D. Lilleland (1946). Rapid determination of potassium and sodium in plant material and soil extracts by flam photometry. Proc. Amer. Soc., Hort. Sci., 48: 341-346.

Bunzen, J.N.P., Guichard, J. Labbr and J. Trenchant (1969). In "Practical Manual of Gas Chromatography". (J. Ttenchant, ed.). El-Seivier, Publ. Comp. Amesterdam, Netherland.

Cantore, V., B. Pace and R. Albrizio (2009). Kaolin-based particle film technology affects tomato physiology, yield and quality. Environmental and Experimental Botany, 66: 279-288.

Dufault, R.J. and W.M. Hair (1991). Influence of cell size, hydrogel, and drought stress on bell pepper transpiration, water usage, and growth. Hort. Science, 26 (6): 689.

El-Ghamriny, E.A., A. Bardisi, A.N. Fayad and R.S. Anwar (2005). Growth plant, water relations and chemical constituents of potato plants as affected by water quantity and some antitranspirants under sandy soil conditions. Zagazig J. Appl. Res., 32 (3): 739-766.

Emesih, G.C., R.G. Moreina and M.A. Barrufet (1999). Evaluation of modified starches for improved oil recovery. Appl. Eng. Agric., 15: 237-242.

Gewefiel, S.G., G.A.A. Bishr, M. Reda, Kamelia and M. Khater, Rania (2009). Some factors affecting Nicotiana gluca growth and active ingredients: ii-effect of irrigation water rate and antitranspirants. J. Agric. Sci. Mansoura Univ., 34 (4): 3519-3531.

Glenn, D.M., G.J. Puterka, S.R. Drake, T.R. Unruh. A.L. Knight and P. Baherle (2001). Particle film application influences apple leaf 
physiology, fruit yield, and fruit quality. Journal of American Society for Horticultural Science, 126: 175-181.

Hoftman, E. (1967). In “Chromotography”, Reinhild. Corp., $2^{\text {nd }}$ Ed. p. 208515.

Jifon, J.L. and J.P. Syvertsen (2003). Kaolin particle film application can increase photosynthesis and water use efficiency of 'Ruby Red' grapefruit leaves. J. Amer. Soc. Hort. Sci., 128: 107-112.

Khater, M. Rania (2010). Effect of some agriculture treatments on the growth and active ingredients of Nicotiana gluca under Sinai conditions. Ph.D. Thesis. Fac. Agric. Zagazig Univ., Egypt.

Koch, F.C. and T.L. Mc-Meekin, (1924). A new direct nesslarization microKjeldahl method and modification of the Nesslar folia reagent for ammonia. J. Amer. Chem. Soc., 46: 2066.

Kosterna, E., B. Zaniewicz, R.R. Anna and J. Franczuk (2012). The effect of agro-hydrogel and irrigation on celeriac yield and quality. Folia Hort., 24 (2): 123-129.

Liang, Z., F. Zhang, M. Shao and J. Zhang (2002). The relations of stomata conductance, water consumption, growth rate to leaf water potential during soil drying and rewarding cycle of wheat (Triticum aestivum). Bot. Bull. Acad. Sci., 43: 187-192.

Mahfouz, S.A. (1997). Effect of some antitranspirants on the growth and chemical components of rosella plant under limited irrigation conditions. M.Sc. Thesis, Fac. Agric., Minufiya Univ. Egypt.

Marotti, M., R. Piccaglia and E. Giovanelli (1996). Differences in essential oil composition of basil (Ocimum basilicum L.) Italian cultivars related to morphological characteristics. J. Agric. Food Chem., 44: 3926-3929.

Martinez, P.F., S.A.A. Tartoura and D. Roca (2001). Air humidity, transpiration and blossom-end rot in soilless sweet pepper culture. Acta. Hort., 559: 425-429.

Moftah, A.E. and A.I. Al-Humaid (2005). Effects of kaolin and pinolene film-forming polymers on water relations and photosynthetic rate of tuberose (Polianthes tuberosa L.), Agricultural Sciences, 18 (1): 3549.

Moftah, A.E. (1997). The response of soybean plant grown under different water regimes to antitranspirants application. Ann. Agric. Sci. Moshtohor, 35 (1): 263-292.

Nakano, A. and Y. Uehara (1996). The effect of kaolin clay on cuticle transpiration in tomato. Acta. Hort., 440: 233-238.

Nnadi, F. and C. Brave (2011). Environmentally friendly superabsorbent polymers for water conservation in agricultural lands. J. Soil Sci. Environ., 2 (7): 206-211. 
Ozcan, M. and J.C. Chalchat (2002). Essential oil composition of Ocimum basilicum L. and Ocimum minimum L. in Turky. Czech J. Food Sci., 20: 223-2280.

Prakash, M. and K. Ramachandran (2000). Effects of chemical ameliorants in brinjal (Solanum melongena L.) under moisture stress conditions. Journal of Agronomy and Crop Science, 185: 237-239.

Sajjadi, S.E. (2006). Analysis of the essential oils of two cultivated basil (Ocimum basilicum L.) from Iran. Daru, 14 (3): 128-130.

Saudan, S. R., N.P. Parbal, S.S. Singh and K. Sing (1999). Use of dust mulch and antitranspirants for improving water use efficiency of menthol mint. Journal of Medicinal and Aromatic Plant Science, 23 (1): 2933.

Snedecor, G.W. and W.G. Cochran (1980). In "Statistical methods" (7th Ed.) Iowa State Univ. Press, Amer., Iowa, USA.

Taylor, K.C. and R.G. Halfacre (1986). The effect of hydrophilic polymer on media water retention and nutrient availability to Ligustrum lucidum. Hort. Sci., 21: 1159-1161.

Troug, E. and A. Mayer, (1939). Improvement in the direness colorimetric method for phosphorus and arsenic. Ind. Eng. Chem. Anal., 1: 136139. 


\title{
تأثير الهيدروجل والمعاملة بمضادات النتح على إنتاجية نبات الريحان
}

\author{
رانية مرتضي رضا خاطر \\ قسم النباتات الطبية و العطرية، مركز بحوث الصحر اء، المطرية، القاهرة، مصر
}

أجريت هذه الدراسة بمحطة بحوث القنطرة الثرق، شمال سيناء، التنابعة لمركز

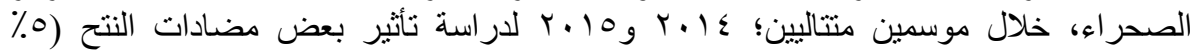

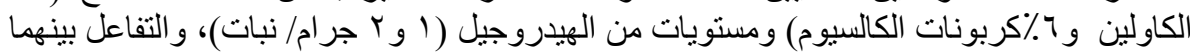

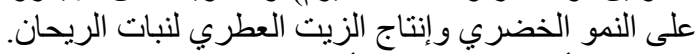

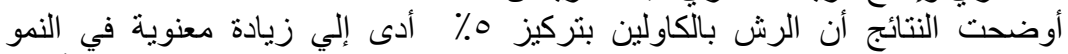

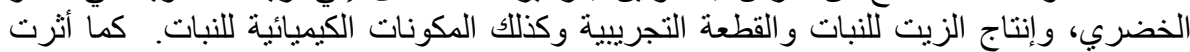

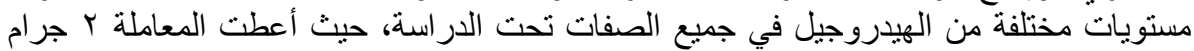

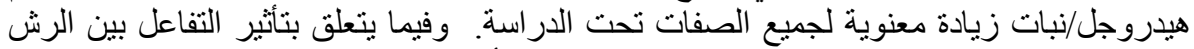

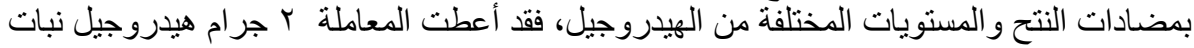

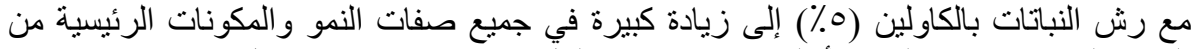

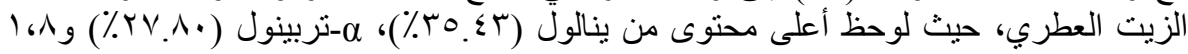

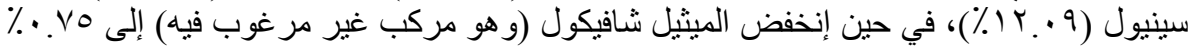
مقارنة بالكنترول و باقي المعاملات.

Egyptian J. Desert Res., 65, No. 2, 193-214 (2015) 